\title{
Metallothionein Synthesis and Degradation in Indian Childhood Cirrhosis Fibroblasts
}

\author{
SI HOUN HAHN, MARK L. BRANTLY, CONSTANCE OLIVER, MEGAN ADAMSON, \\ STEPHEN G. KALER, AND WILLIAM A. GAHL \\ Section of Human Biochemical Genetics, Human Genetics Branch. National Institute of Child Health \\ and Human Development, National Institutes of Health, Bethesda, Maryland 20892
}

\begin{abstract}
Indian childhood cirrhosis (ICC) is a fatal liver disease characterized by the accumulation of coppersulfur aggregates. We demonstrated that cultured fibroblasts from a patient with ICC contain vesicular aggregates, fibrillar whorls, and crystalloids along with dilated rough endoplasmic reticulum filled with flocculent material. Although the copper content of the fibroblasts was normal, both basal and metal-induced metallothionein (MT) synthesis was reduced in the ICC cells. The lower MT synthesis in ICC cells was seen at copper concentrations of 100,200 , and $400 \mu \mathrm{M}$, zinc concentrations of 50 and $100 \mu \mathrm{M}$, and a cadmium concentration of $2 \mu \mathrm{M}$. The lower MT synthesis in ICC cells was not due to failure of the cells to take up copper because ${ }^{67} \mathrm{Cu}$ uptake kinetics were normal in the mutant cells. MT degradation was also normal in the ICC cells. The size of human MT IIA mRNA was normal in the ICC cells, but its amount was reduced under both basal and metal-induced conditions. The MT IIA gene, which is the predominant MT gene in human beings, showed no sequence alterations in any of its exons, introns, or promoter region in the ICC cells compared with normal cells. These studies demonstrate that this case of ICC represents a genetic disease with some level of expression in cultured fibroblasts; the basic defect may involve insufficient MT mRNA and protein synthesis for the copper load present. However, it remains to be determined whether reduced MT synthesis is a primary or secondary phenomenon. (Pediatr Res 35: 197-204, 1994)
\end{abstract}

\section{Abbreviations}

ICC, Indian childhood cirrhosis

MT, metallothionein

EMEM, Eagle's minimal essential medium

PCR, polymerase chain reaction

hMT IIA, human metallothionein IIA from copper pipes. Alternatively, a genetic defect of copper metabolism may produce the hepatic granules and cirrhosis (1, $2,9,10)$; epidemiologic and family studies support this explanation $(1,9)$. Some combination of environmental and genetic influences may also be responsible for ICC (8). Although most cases of ICC occur in India, several patients have been reported in Germany and other countries $(10-15)$.

We recently described an American child, the product of a consanguineous marriage, with all the clinical, biochemical, and histologic criteria of ICC (8). On the basis of the finding of striking morphologic abnormalities in this patient's cultured fibroblasts, we used these cells to investigate the basic defect in this case of ICC. In particular, we examined the production and turnover in cultured fibroblasts of the primary intracellular copper-binding protein, MT.

MT is a $6500-\mathrm{D}$ cytoplasmic protein containing 20 cysteine residues and no aromatic amino acids (16). It binds several heavy metals, including copper, zinc, and cadmium. Copper MT, for example, contains 11 to 12 copper ions, six bound to the amino terminal portion (cluster B), and five or six in the carboxy terminal portion (cluster A) (17). MT is also induced at the transcriptional level by cadmium, zinc, copper, and dexamethasone. At least five functional human MT genes exist, including the brain-specific MT III (18), and five pseudo-genes, but MT IIA (19) is the major gene, responsible for $80 \%$ of human MT synthesis. The promoter region of MT IIA contains several metal regulatory elements and a glucocorticoid regulatory element in addition to basal regulatory elements (20). Copper induction of MT IIA is thought to occur by binding of a copper-metal regulatory factor complex to a metal regulatory element, with enhanced transcription.

To evaluate the possibility that MT metabolism is abnormal in our patient with ICC, we investigated the synthesis, induction, and degradation of MT in his cultured fibroblasts. We also determined the MT IIA mRNA content of ICC fibroblasts and the DNA sequence of the promoter and structural regions of the MT IIA gene in this individual.

\section{MATERIALS AND METHODS}

Cell culture. Normal fibroblast strains GM 3349, 3440, 3529 , $3651,3652,5659,5757$, and 5758 and Menkes' strains GM 1057, 1981, and 3700 were obtained from the Human Genetic Mutant Repository (Camden, NJ). Normal fibroblast strains SH and MD and cultured fibroblasts from the patient with ICC were grown from a 4-mm punch biopsy specimen obtained after informed consent. Cells were grown at $37^{\circ} \mathrm{C}$ in Dulbecco's DMEM (Quality Biofluids, Gaithersburg, MD) containing 10\% FCS (GIBCO, Grand Island, NY), glutamine ( $2 \mathrm{mM})$, penicillin $(100 \mathrm{IU} / \mathrm{mL})$, and streptomycin $(100 \mu \mathrm{g} / \mathrm{mL})$, and were maintained with an ambient $\mathrm{CO}_{2}$ content of $5 \%$. No copper was added to this media which, including the FCS, had a copper concentration of $11 \mu \mathrm{g} / \mathrm{L}$. Fibroblast and media copper were measured by
Correspondence to: William A. Gahl M.D. Ph.D. National Institutes of Health National Institute of Child Health and Human Development, 9000 Rockville Pike. Building 10, Room 9S242, Bethesda, MD 20892. 
atomic absorption analysis (Doctors Lee Blum and Nancy Dickens, National Medical Services, Inc., Willow Grove, PA). Electron microscopy of fibroblasts was performed using a JEOL-100 CX electron microscope (Japanese Electron Optics, Ltd., Peabody, MA) after fixation with $2 \%$ glutaraldehyde $/ 2 \%$ formaldehyde, postfixation in $1 \%$ osmium tetroxide and embedding in epon. Lysosomes were localized by the acid phosphatase method of Barka and Anderson (21) with $\beta$-glycerophosphate as substrate.

MT synthesis. Confluent cells grown in $35 \mathrm{~mm}$ diameter tissue culture wells (Costar, Cambridge, MA) were preincubated for 24 $\mathrm{h}$ in EMEM containing $20 \%$ dialyzed FCS. The medium was replaced with cysteine-free EMEM plus $20 \%$ dialyzed FCS for 2 $\mathrm{h}$, and the cells were labeled with $50 \mu \mathrm{Ci} / \mathrm{mL}$ of $\mathrm{L}-\left[{ }^{35} \mathrm{~S}\right]$-cysteine (specific activity, $980 \mathrm{Ci} / \mathrm{mmol}$; New England Nuclear, Boston, MA) in cysteine-free EMEM plus $0.5 \%$ dialyzed FCS. After labeling for a designated time $(45-135 \mathrm{~min})$, the medium was removed. The cells were washed twice with PBS and lysed in 100 $\mu \mathrm{L}$ of ice-cold $50 \mathrm{mM}$ Tris (pH 7.4), $150 \mathrm{mM} \mathrm{NaCl}, 5 \mathrm{mM}$ DTT, $1 \%$ Nonidet $\mathrm{P}-40$ by scraping with a rubber policeman. The lysates were centrifuged at $15000 \times g$ for $15 \mathrm{~min}$, and aliquots of the supernatant were frozen at $-80^{\circ} \mathrm{C}$. The supernatants were carboxymethylated to prevent polymerization by incubation with $0.3 \mathrm{M}$ iodoacetic acid in $1 \mathrm{M}$ Tris, $\mathrm{pH} 8.4$, at room temperature in the dark for $45 \mathrm{~min}$. After mixing with $4 \mathrm{vol}$ of sample buffer (62.5 mM Tris- $\mathrm{HCl}, \mathrm{pH} 6.8,10 \%$ glycerol, $5 \% \beta$-mercaptoethanol, $0.05 \%$ bromophenol blue), the samples were loaded directly onto a $12-22 \%$ gradient non-SDS polyacrylamide gel and electrophoresed as described (30). An equal amount of trichloroacetic acid-precipitable radioactivity was loaded on each lane. After electrophoresis, the gel was dried and exposed to Kodak XAR-2 film (Eastman Kodak, Rochester, NY) at $-70^{\circ} \mathrm{C}$.

For copper induction of MT synthesis, $100-400 \mu \mathrm{M} \mathrm{CuSO}_{4}$ was present in all media for $9 \mathrm{~h}$ before harvesting. Zinc, cadmium, and dexamethasone inductions were performed in a similar fashion.

Mouse MT I cDNA, isolated from a library prepared by Doctors Tsao Hsu and Dean Hamer of the National Cancer Institute, was sequenced and shown to match the published sequence (22). RNA was prepared with the Riboprobe Gemini II kit (Promega, Madison, WI) and translated using a cell-free wheat germ system (23).

$M T$ degradation. After preincubation, cells were pulsed with ${ }^{35} \mathrm{~S}$-cysteine $(50 \mu \mathrm{Ci} / \mathrm{mL})$ for $1 \mathrm{~h}$ as described above. After washing twice with PBS, the cells were placed in EMEM with $20 \%$ dialyzed FCS containing $20 \mu \mathrm{M}$ cycloheximide and $0.5 \mu \mathrm{M}$ cold cysteine to inhibit the incorporation of any residual radioactive cysteine into newly synthesized proteins. The cycloheximide alone inhibited ${ }^{35} \mathrm{~S}$-cysteine incorporation into protein by $83 \%$, while maintaining viability between 84 and $93 \%$, as assessed by trypan blue exclusion. After chase periods of $0,24,48$, 72 , and $96 \mathrm{~h}$, the cells were harvested and the MT carboxymethylated. Electrophoresis was performed as described above with equal amounts of protein in each lane. Autoradiography and densitometry were performed, and the natural $\log$ of density was plotted as a function of chase time to calculate a $t_{1 / 2}$ for MT degradation.

${ }^{67} \mathrm{Cu}$ uptake. Fibroblasts were grown to confluence in six-well plates $(3.5 \mathrm{~cm}$ diameter wells, Costar 3506$)$. The cells were washed twice with $1 \mathrm{~mL}$ of cold EMEM and exposed to $750 \mu \mathrm{L}$ of EMEM containing $3.5 \mu \mathrm{Ci}^{67} \mathrm{Cu}(1-2 \mathrm{mCi} / \mu \mathrm{g}$, Isotope Distribution Office, Brookhaven National Laboratory, Upton, NY, or Los Alamos National Laboratory, Los Alamos, NM) and 0 to 50 $\mu \mathrm{M}$ nonradioactive $\mathrm{CuCl}_{2}(2 \mathrm{mM}$ stock $)$. After incubating at $37^{\circ} \mathrm{C}$ for $1 \mathrm{~h}$, the cells were washed three times with $1 \mathrm{~mL}$ of cold PBS, harvested using $0.25 \%$ trypsin at $4^{\circ} \mathrm{C}$ for $15 \mathrm{~min}$, and again washed three times with $0.75 \mathrm{~mL}$ cold $\mathrm{PBS}$. The final pellet was resuspended in $0.5 \mathrm{~mL} \mathrm{H}_{2} \mathrm{O}$ and sonicated to homogenization. Duplicate aliquots were removed for assay of protein by the bicinchoninic acid method (24) and for measurement of radioactivity in a Beckman LS-250 scintillation counter (Beckman Instruments, Fullerton, CA). For each cell strain at each concentration of copper, duplicate wells were counted; a separate well maintained on ice served as a control for copper binding as opposed to uptake. At $50 \mu \mathrm{M}$, copper uptake was linear with time for at least $4 \mathrm{~h}$. This linearity, along with the fact that the $4^{\circ} \mathrm{C}$ control contained only approximately $10 \%$ of the radioactivity present in the $37^{\circ} \mathrm{C}$ samples, indicated that uptake, rather than binding, was being measured.

Human metallothionein IIA. A genomic DNA clone of human MT IIA (hMT IIA) (American Type Culture Collection, Rockville, MD) was digested by $H$ indIII restriction and separated on a $1 \%$ agarose gel $(25)$. The hMT IIA band was cut out, extracted with phenol-chloroform, and resuspended in $10 \mathrm{mM}$ TRIS, 1 $\mathrm{mM}$ EDTA. The hMT IIA DNA probe was prepared using the Promega Prime-a Gene system based on a method developed by Feinberg and Vogelstein $(26,27)$ with $\left({ }^{32} \mathrm{P}\right)$ deoxycytidine triphosphate $(3000 \mathrm{Ci} / \mathrm{mmol}$, Amersham, Arlington Heights, IL).

$R N A$ studies. PolyA mRNA was isolated from fibroblasts with and without a 9-h exposure to copper, cadmium, or zinc with the Fast Track mRNA Isolation Kit (Invitrogen, San Diego, CA). RNA was size separated by electrophoresis on a $1.2 \%$ agarose/ formaldehyde gel and transferred to nitrocellulose paper. The RNA filter was prehybridized for $6 \mathrm{~h}$, followed by hybridization for $36 \mathrm{~h}$ with ${ }^{32} \mathrm{P}$-labeled genomic hMT-IIA probe based on a method developed by Lehrach et al. (28). After it was washed for $15 \mathrm{~min}$ twice at room temperature in $2 \times \mathrm{SSC}, 0.1 \% \mathrm{SDS}$, then in $0.5 \times \mathrm{SSC}, 0.1 \% \mathrm{SDS}$, followed by wash of $15-20 \mathrm{~min}$ at $65^{\circ} \mathrm{C}$ in $0.1 \times \mathrm{SSC}, 0.1 \% \mathrm{SDS}$, the filter was exposed to Kodak XAR2 film at $-70^{\circ} \mathrm{C}$ with an intensifying screen.

For slotblots, fibroblasts were harvested, washed once with PBS, and suspended in $45 \mu \mathrm{L}$ of cold $10 \mathrm{mM}$ Tris, $\mathrm{pH} 7.0$, containing $1 \mathrm{mM}$ EDTA. The cells were lysed by adding $5 \mu \mathrm{L}$ of $5 \% \mathrm{NP}-40$ and by mixing on ice for $5 \mathrm{~min}$. The nuclei were pelleted, and $50 \mu \mathrm{L}$ of supernatant was transferred to an Eppendorf tube containing $30 \mu \mathrm{L}$ of $20 \times$ SSC plus $20 \mu \mathrm{L}$ of $30 \%$ (wt/ vol) formaldehyde. The mixture was incubated at $60^{\circ} \mathrm{C}$ for 15 min and blotted to nitrocellulose paper using the Minifold II slot-blot system from Schleicher and Schuell Co. (Keene, NH). The hybridization and washing steps were the same as for the Northern blots. $\beta$-Actin probe was purchased from Clontech Co. (Palo Alto, CA) and labeled with ${ }^{32}$ P-deoxycytidine triphosphate using random primer labeling.

Sequencing. Extraction of whole genomic DNA from fibroblasts was accomplished as described (25). MT genomic DNA was amplified by PCR as two overlapping fragments using primer pairs 5'-AAGCTTGTGGCTTCTTCTCCTTACTCTTC and 5'CAGGAGCAGTTGGGATCCATGGCGAGC for nucleotide positions -765 to 92 , and 5'-GCCGCCTTCAGGGAACTGACCGC and 5'-CAGAATCAAGTCAAAGCTG for positions -197 to 910 , relative to the translation initiation site in normal MT genomic DNA (19). Each fragment was amplified in $100 \mu \mathrm{L}$ of $10 \mathrm{mM}$ Tris- $\mathrm{HCl}$, pH $9.0,50 \mathrm{mM} \mathrm{KCl}, 1.5 \mathrm{mM} \mathrm{MgCl}_{2}$, $0.001 \%(\mathrm{wt} / \mathrm{vol}$ ) gelatin, $200 \mu \mathrm{M}$ of each deoxyribonucleoside triphosphate, $20 \mathrm{pmol}$ of sense and antisense primer, 2.5 units of Taq DNA polymerase (Perkin Elmer Cetus, Norwalk, CT), and $2.5 \%$ (wt/vol) DMSO. Genomic DNA (300 ng) was added after denaturation for $5 \mathrm{~min}$ at $100^{\circ} \mathrm{C}$. The PCR program was one cycle of $94^{\circ} \mathrm{C}$ for $2 \mathrm{~min}, 30$ cycles of $94^{\circ} \mathrm{C}$ for $1 \mathrm{~min}, 60^{\circ} \mathrm{C}$ for $2 \mathrm{~min}$, and $72^{\circ} \mathrm{C}$ for $3 \mathrm{~min}$ followed by $5 \mathrm{~min}$ of elongation at $72^{\circ} \mathrm{C}$. Fragments of PCR product were inserted into vector pCR 1000 supplied by Invitrogen (San Diego, CA). Plasmid DNA was isolated using the Magic Minpreps DNA purification system (Promega), and used to transform competent Escherichia coli cells. Several plasmid DNA clones containing the PCR fragments were sequenced by the Sanger method (29) with T7DNA polymerase supplied by United States Biochemical (Cleveland, $\mathrm{OH}$ ). 
RESULTS

ICC fibroblasts. On light microscopy, cytoplasmic vacuoles were prominent within the ICC fibroblasts. On electron microscopy, the fibroblast changes resembled those in the liver, except that the contents were less dense. Three abnormal findings characterized virtually all of the ICC fibroblasts, even when no copper was added to the medium. First, abundant vesicular aggregates, resembling the hepatic aggregates typical of ICC, increased in number and size with increasing time in culture (Fig. 1 $A$ ). The aggregates appeared within vesicles that stained positive for acid phosphatase (Fig. $1 B$ ). Second, inclusions containing fibrillar whorls and crystalloids were extremely common and prominent findings (Fig. 1C). These inclusions also stained positively for acid phosphatase and displayed the structure of lysosomes. Finally, the cisternae of the rough endoplasmic reticulum were uniformly dilated and filled with flocculent material (Fig. 1D). The dense aggregates, fibrillar whorls and crystalloids, and dilated cisternae did not appear to be nonspecific toxic changes because they were not present in fibroblasts cultured from patients with other disorders of copper metabolism, such as Wilson's disease or Menkes' disease (data not shown).

The ICC fibroblasts contained $32 \pm 3$ (SD) ng of copper/mg of protein $(n=4)$. Three normal control cell strains (GM 5659. GM 3349, and MD) had copper values of 13,22 , and $34 \mathrm{ng} / \mathrm{mg}$ protein.

MT synthesis. The relatively low molecular weight and high cysteine content of MT permitted measurement of its synthesis using ${ }^{35}$ S-cysteine incorporation and autoradiography after PAGE. After carboxymethylation to prevent polymerization, human fibroblast MT migrated much farther than other ${ }^{35} \mathrm{~S}$ containing proteins (Fig. $2 A$, lanes $l$ and 2 ). Its mobility coincided with that of authentic mouse ${ }^{35} \mathrm{~S}-\mathrm{MT} \mathrm{I}$, produced by cellfree in vitro translation (Fig. 2A, lanes 3 and 4 ), and with that of authentic rabbit $\mathrm{MT}$, which was identified by coomassie blue staining (Fig. 2B, left panel). The fibroblast MT was also identified by its copper inducibility and its migration in the 6-10000 $D$ range, with autoradiography and radioactive markers (Fig. $2 B$, right panel). For normal. Menkes' and ICC fibroblasts, the density of the ${ }^{35} \mathrm{~S}-\mathrm{MT}$ band increased with increasing duration of ${ }^{35} \mathrm{~S}$-cysteine exposure (Fig. 3). However, despite roughly equivalent incorporation of ${ }^{35} \mathrm{~S}$ into total protein, the ICC fibroblasts synthesized substantially less ${ }^{35} \mathrm{~S}-\mathrm{MT}$ compared with four different normal cell strains and three different Menkes' strains. Figure 3 shows representative data.

MT synthesis by normal. Menkes', and ICC fibroblasts was

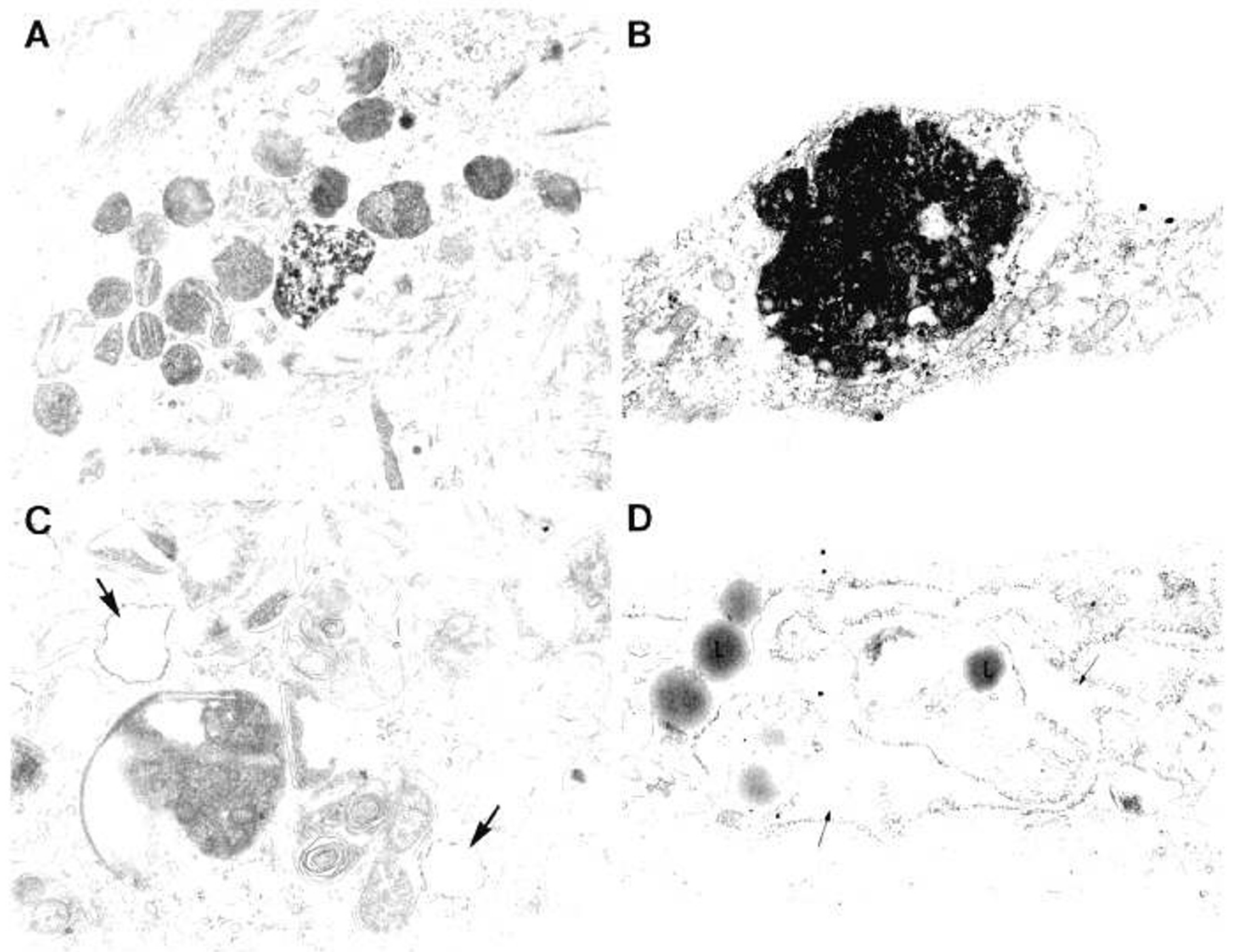

Fig. 1. Electron micrographs of ICC cultured fibroblasts. $A$. Typical clustering of membrane-bound vesicles containing materials of varying density $(\times 13400) . B$. A large lysosome containing aggregates is stained intensely for acid phosphatase. This was typical of the fibroblast inclusions. The nucleus is not shown $(\times 15000)$. C. Fibrillar whorls and crystalloid-containing inclusions are prominent. Flocculent material fills the swollen cisternae of the endoplasmic reticulum (arrons) $(\times 24000)$. D. Rough endoplasmic reticulum (arrows), filled with flocculent material. Numerous lipid droplets $(L)$ surround endoplasmic reticulum $(\times 24000)$. 

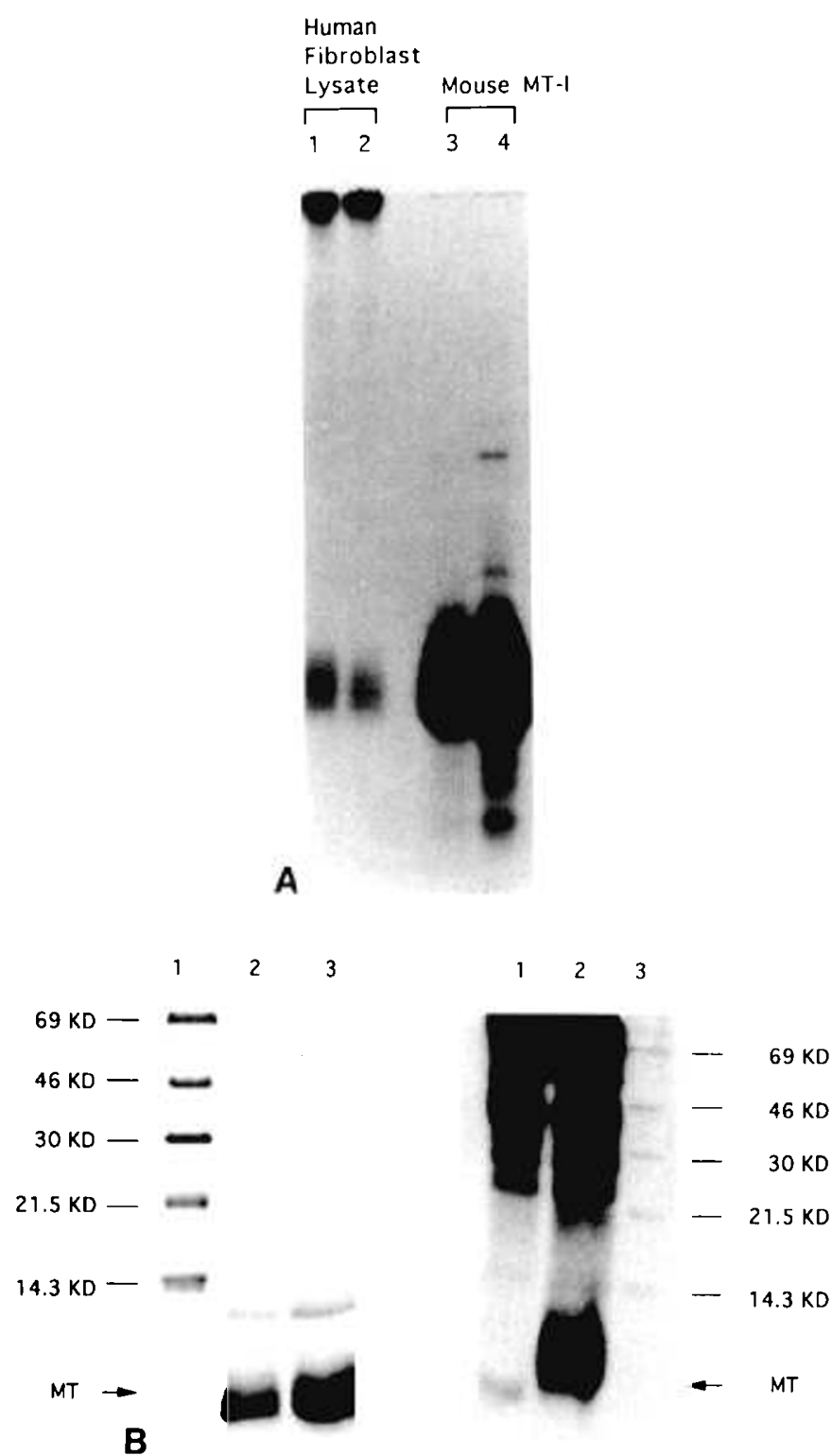

Fig. 2. PAGE of normal human fibroblast proteins and authentic mouse MT I. A, Human fibroblasts (GM 5758) were pulsed for $1 \mathrm{~h}$ with ${ }^{33} \mathrm{~S}$-cysteine, harvested, and lysed in $100 \mu \mathrm{L}$ of buffer. After carboxymethylation to prevent MT polymerization. $7.6 \mu \mathrm{L}$ (lane l) and $14 \mu \mathrm{L}$ (lane 2) were loaded in a $20 \%$ SDS polyacrylamide gel, electrophoresed, and subjected to autoradiography. Lanes 3 and 4 contained $2 \mu \mathrm{L}$ and 4 $\mu \mathrm{L}$, respectively, of ${ }^{35} \mathrm{~S}$-cysteine-labeled mouse MT I prepared by in vitro translation of the authentic RNA. The fibroblast lysate contains ${ }^{35} \mathrm{~S}$ protein, which migrates with mouse MT I and is easily distinguishable from the higher molecular weight ${ }^{35} \mathrm{~S}$-labeled proteins at the top of the gel. $B$. Human fibroblasts (GM 5659) were exposed to 0 or $800 \mu \mathrm{M}$ $\mathrm{CuSO}_{4}$ for $9 \mathrm{~h}$ and to ${ }^{35} \mathrm{~S}$-cysteine for $1 \mathrm{~h}$, harvested, and loaded on a $20 \%$ non-SDS polyacrylamide gel after carboxymethylation with iodoacetic acid. Authentic rabbit MT (Sigma) and ${ }^{14} \mathrm{C}$-labeled molecular weight markers (Amersham), were electrophoresed on the same gel, which was cut in half. The left half was stained with coomassie blue, whereas the right half was fixed and autoradiographed. Lane panel: lane 1, ${ }^{14} \mathrm{C}$-protein standards; lane 2, rabbit MT $(10 \mu \mathrm{g})$; lane 3. rabbit MT $(30 \mu \mathrm{g})$. Right panel: lane $1,8.2 \mu \mathrm{L}$ of fibroblast lysate without copper induction; lane 2, $10.4 \mu \mathrm{L}$ of fibroblast lysate with $800 \mu \mathrm{M}$ copper induction; lane $3,{ }^{14} \mathrm{C}$-standards. The right panel was compressed more than the left by the fixative.

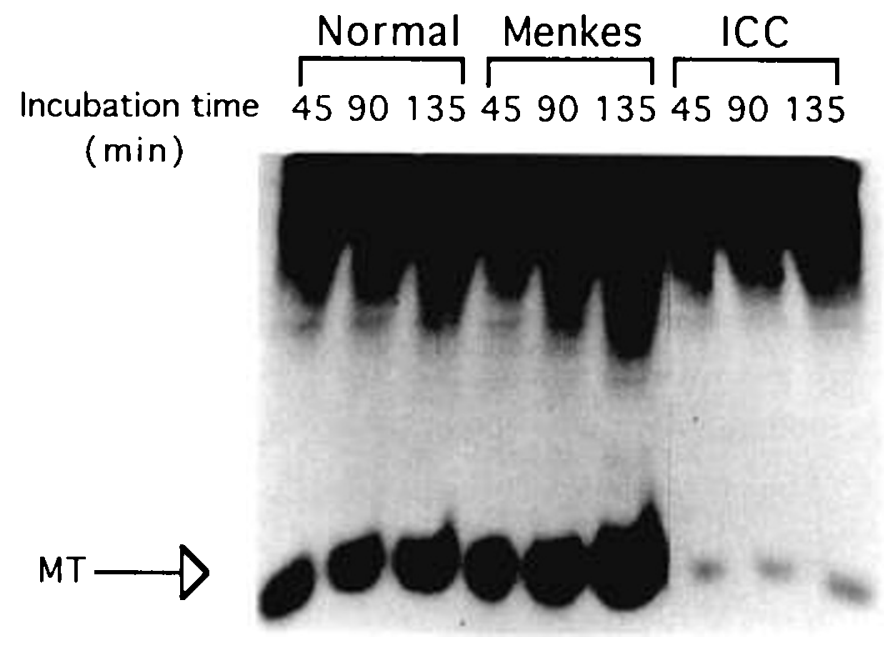

Fig. 3. Production of ${ }^{35} \mathrm{~S}-\mathrm{MT}$ after different times of exposure to ${ }^{35} \mathrm{~S}$ cysteine. Representative normal (GM 3652) and Menkes' (GM 1981) cell strains, as well as ICC fibroblasts, were pulsed for 45.90 , or $135 \mathrm{~min}$ with ${ }^{35} \mathrm{~S}$-cysteine and harvested. Equivalent amounts of trichloroacetic acid-precipitable radioactivity $(50000 \mathrm{cpm})$ of the carboxymethylated lysates were loaded onto the same $12-22 \%$ gradient, non-SDS polyacrylamide gel, electrophoresed, and autoradiographed. Irrelevant intervening lanes between the Menkes' and ICC lanes were removed and the gel pieces placed side by side. Arrow points to MT, migrating with an apparent molecular weight of $6500 \mathrm{D}$. For each cell strain. MT production increased with increased pulse time.

measured after growth in different concentrations of copper sulfate. For all three cell strains, MT synthesis increased as the exogenous copper concentration was increased to $400 \mu \mathrm{M}$ (Fig. 4). There was no apparent cellular toxicity at this concentration. As expected (30), Menkes' cells showed greater than normal MT synthesis at all copper concentrations. ICC fibroblasts displayed negligible MT synthesis when no exogenous copper was present: MT synthesis in the presence of $400-\mu \mathrm{M}$ copper was approximately equal to normal MT synthesis in the absence of added copper (Fig. 4).

Zinc at $50 \mu \mathrm{M}$ and $100 \mu \mathrm{M}$ significantly enhanced MT synthesis in normal fibroblasts. ICC cells again showed low basal MT synthesis but significant induction by zinc (Fig. 5.A). Even the induced levels, however, were not as great as the normal basal level of MT synthesis. Cadmium induced MT synthesis substantially in ICC cells, but the induced level was much less than that observed in normal cells (Fig. $5 B$ ). MT induction by dexamethasone was similar in normal and ICC cells.

${ }^{67} \mathrm{Cu}$ uptake. Measurement of ${ }^{67} \mathrm{Cu}$ uptake into ICC and normal fibroblasts showed no differences in uptake kinetics (Fig. 6). Two normal cell strains showed $\mathrm{Km}$ values for copper uptake of 5.8 and $3.6 \mu \mathrm{M}$; the $\mathrm{Km}$ for the ICC cells was $5.1 \mu \mathrm{M}$. Similarly, the $V_{\max }$ values were 54 and $49 \mathrm{pmol} / \mathrm{mg}$ protein $/ \mathrm{h}$ for normal cells and $55 \mathrm{pmol} / \mathrm{mg}$ protein/h for the ICC cells.

$M T$ degradation. A 60 -min pulse exposure to ${ }^{35} \mathrm{~S}$-cysteine at the end of a 9-h induction by $800 \mu \mathrm{M}$ copper resulted in substantial ${ }^{35}$ S-MT production by normal fibroblasts (Fig. 7). A 96-h chase period revealed logarithmic decay of the ${ }^{35} \mathrm{~S}-\mathrm{MT}$ with a $t_{1 / 2}$ of $71.4 \pm 8.6$ (SD) $h$. In the same experiment, ICC fibroblasts exhibited much less initial ${ }^{35} \mathrm{~S}-\mathrm{MT}$ production (Fig. 7) but a similar $\log /$ linear decay rate $\left(t_{1 / 2}=64.5 \pm 6.0 \mathrm{~h}\right)$.

hMT IIA $m R N A$ production. Northern-blot analysis revealed hMT IIA mRNA of normal size in ICC compared with control fibroblasts (Fig. 8A). Induction by heavy metals was less in ICC than in normal or Menkes' cells. This finding was confirmed by slot-blot analysis. Although $\beta$-actin mRNA loading was roughly equivalent, both basal and metal-induced hMT IIA mRNA were less in ICC compared with normal cells (Fig. $8 B$ ).

hMT IIA sequencing. For the three exons of hMT IIA, the 


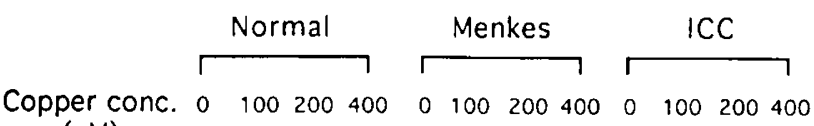
(uM)

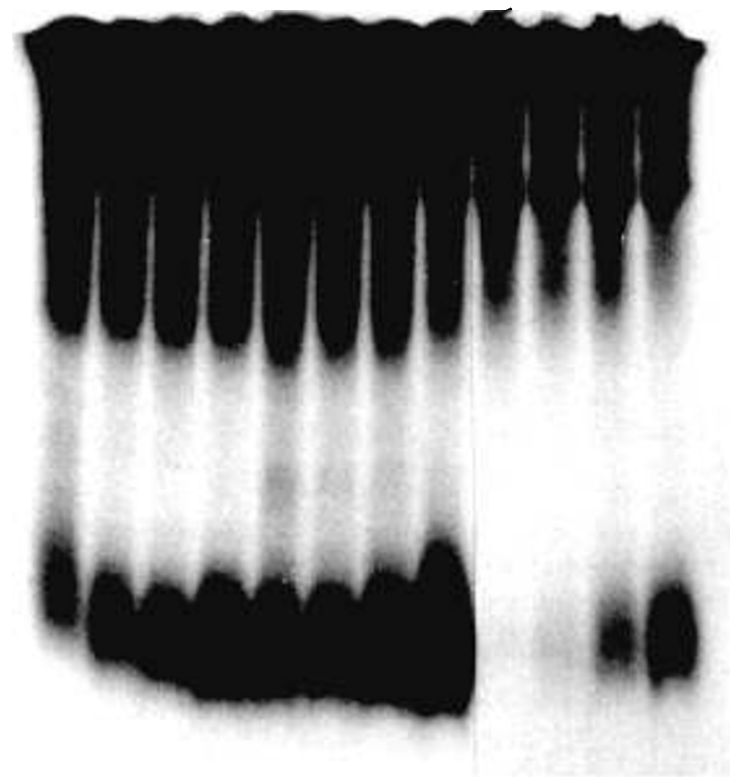

Fig. 4. MT induction by copper in normal, Menkes', and ICC fibroblasts. Cells were exposed to $0,100.200$ or $400 \mu \mathrm{M} \mathrm{CuSO}$ for $9 \mathrm{~h}$ and to ${ }^{35} \mathrm{~S}$-cysteine for $1 \mathrm{~h}$, as described in Materials and Methods. Equal amounts of trichloroacetic acid-precipitable radioactivity were loaded on each lane of the same $20 \%$ non-SDS gel. Autoradiogram shows copper induction of MT for normal (GM 3652). Menkes' (GM 3700), and ICC cells. Irrelevant intervening lanes between the Menkes' and ICC lanes were removed and the gel pieces placed side by side.

sequences of the authentic gene obtained from ATCC, the normal control cell (GM 5757) gene, and the ICC gene all matched the published sequence $(19,20)$. However, all three genes differed significantly from the published sequence in certain areas of the promoter region (Fig. 9), even though the ATCC clone was

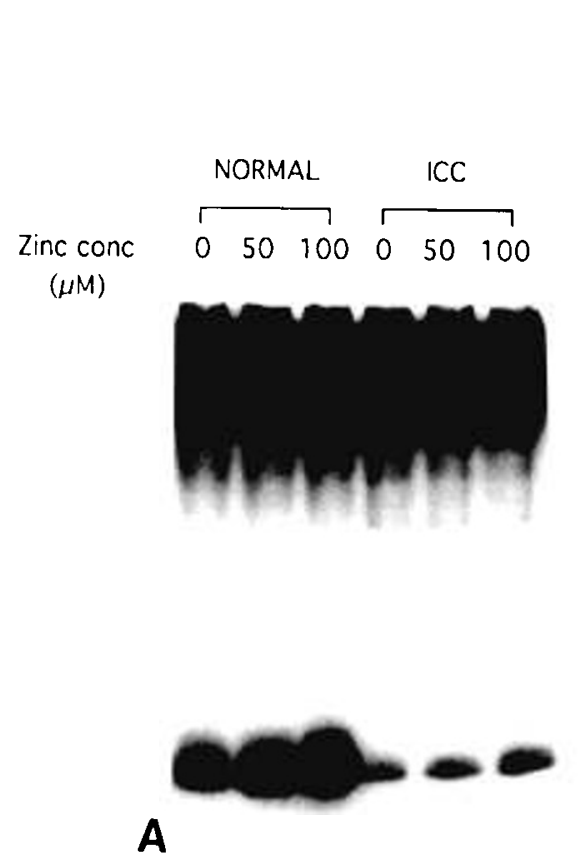

amplified in $E$. coli and the normal and ICC clones were PCR amplified. In every case, the base differences compared with the published sequence were shared by all three clones (Fig. 9). One important change, the addition of four bases in the basal level element, was found in the ICC as well as the normal hMT IIA gene.

\section{DISCUSSION}

As a disease, ICC has evolved from a vague fatal hepatic malady affecting thousands of Indian infants to a distinct entity recognized as involving impaired copper metabolism (1-4). The exact metabolic defect awaits explanation, but its discovery should help reveal how cells normally handle copper.

This investigation advances our understanding of ICC in several ways. First, it establishes that cultured fibroblast structure can be grossly abnormal in ICC (Fig. 1) and that MT protein synthesis and hMT IIA mRNA may be reduced in these cells (Figs. 4, 5, and 8). As alluded to previously (31), whole fibroblast copper levels are normal. Although this finding suggests that the morphologic aberrations may be independent of intracellular copper levels, other explanations are feasible. Abnormal compartmentalization of copper in ICC fibroblasts may exist, e.g. within intracellular aggregates, or it may take months for any type of cell to store copper. This time frame would allow hepatocytes to accumulate copper whereas rapidly dividing fibroblasts could not. Moreover, because copper flux through the fibroblast is limited compared with the hepatocyte, disruption of normal structure could occur in both cells, but only the liver would collect massive amounts of copper.

The finding of abnormalities in our patient's fibroblasts confirms that there is a genetic component to at least some cases of ICC. This finding is consistent with the consanguinity reported in the family of the affected patient (8) and with previous epidemiologic studies in India (1,9). However, it does not eliminate the possibility that increased dietary copper is also required for the disease to be manifest: other genetic disorders also require an environmental influence to be expressed $(8,32)$.

Several straightforward explanations for the reduced MT synthesis observed in ICC fibroblasts have been eliminated. Rapid degradation of MT could make it appear that synthesis was

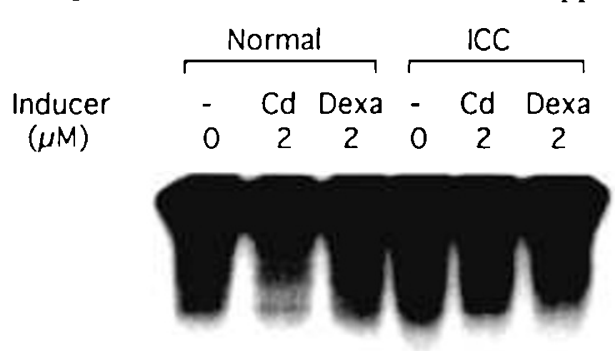

\section{B}

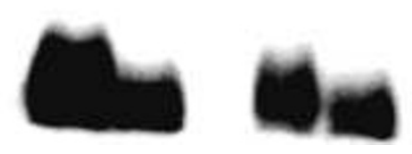

Fig. 5. MT induction by zinc, cadmium, or dexamethasone. Normal (GM 5758) and ICC cells were exposed to the indicated concentrations of $(A)$ zinc chloride or $(B)$ cadmium chloride $(C d)$ or dexamethasone (Dexa) for $9 \mathrm{~h}$ before ${ }^{35}$ S-cysteine labeling. Equal amounts of fibroblast lysate acid-precipitable radioactivity were loaded on a $20 \%$ non-SDS polyacrylamide gel. 


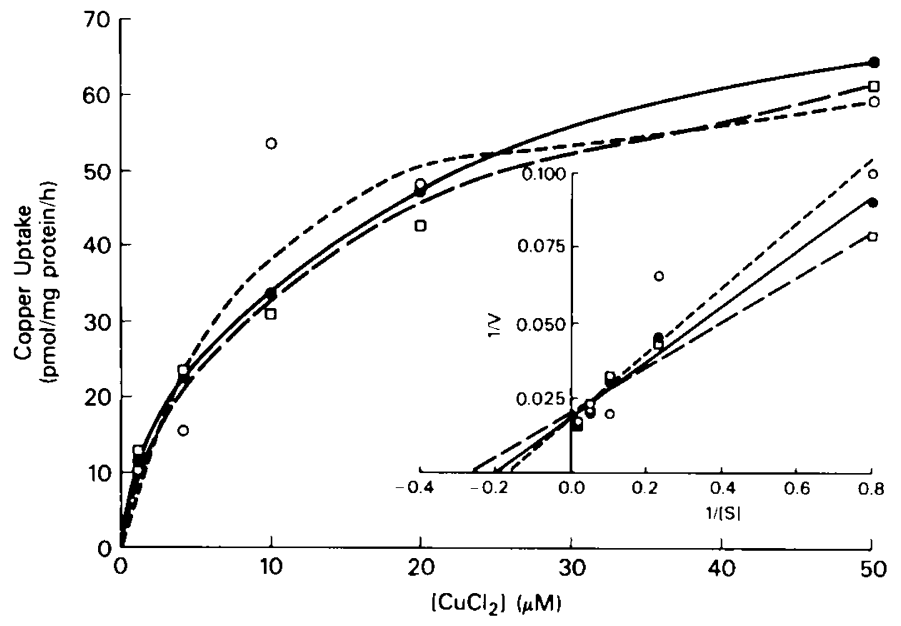

Fig. 6. Copper uptake into normal and ICC fibroblasts. Initial velocity of ${ }^{67} \mathrm{Cu}$ uptake was plotted against copper concentration for normal fibroblast strains GM $3349(\mathrm{O}-\mathrm{O})$ ) and $\mathrm{SH}(\square-\square)$. and for the ICC strain (-C). Points are means of duplicate determinations performed on duplicate culture wells (see Materials and Methods). Inset gives double reciprocal plot, with lines drawn from least-squares calculations. Text gives kinetic parameters.

reduced, but this did not occur in ICC fibroblasts (Fig. 7). In addition, no impaired copper uptake into ICC cells (Fig. 6) existed that would block the elevation of intracellular copper necessary for induction of MT synthesis. Finally, no mutations occurred in the primary DNA sequences of any of the three hMT IIA exons in ICC cells, and the ICC hMT IIA mRNA was normal in size (Fig. $8 \mathrm{~A}$ ); only its amount was reduced.

The evidence suggested a defect in the regulation of MT synthesis. Basal-level MT synthesis was consistently reduced in ICC cells, and although copper, zinc, and cadmium induced some MT, the induced levels in ICC never reached those of normal cells (Figs. 4 and 5). The basal and induced levels of MT IIA mRNA mirrored the MT protein synthesis rates (Fig. 8). A defect in the promoter region of the hMT IIA gene could explain these findings. If the basal level element were mutated, basal MT synthesis would be reduced and even metal induction might not restore it to normal induced levels. If a metal regulatory element were mutated, basal MT synthesis might be reduced because even basal synthesis uses some transcription-enhancing activity at the metal regulatory element. However, the sequences of all critical regulatory elements of the promoter region of hMT IIA were identical in the ICC and normal cells (Fig. 9). This finding, combined with the exon and intron sequence data, rule out a mutation in hMT IIA as the primary cause of this case of ICC.

Feasible explanations for reduced MT synthesis in ICC cells should be consonant with current understanding of the regulation of MT synthesis. This understanding is based on yeast studies, although the structure of MT itself differs in yeast and mammals.
In Saccharomyces cerevisiae, induction of CUP1, which codes for $\mathrm{MT}$, is initiated by binding of $\mathrm{Cu}^{+}$to the amino terminal half of a $24 \mathrm{kD}$ protein, $\mathrm{ACE} 1$, which is rich in basic residues and cysteines (33-35). This $\mathrm{Cu}^{+}$binding causes a conformational change in the amino terminal, DNA-binding domain of ACEI, allowing it to bind to a region of the CUPI promoter, the upstream activating sequence (UASc). Once bound, ACE I functions as a transcription factor. In human cells, the metal regulatory element serves as the metal responsive element in the promoter, and a metal regulatory factor provides the counterpart of ACE1.

Currently, our operating hypothesis is that in ICC, copper is not available or able to induce enough MT to prevent cellular toxicity. Several findings support this tenet. In cultured ICC fibroblasts, the amount of MT synthesis and MT IIA mRNA are not appropriate for the intracellular copper concentrations. At basal copper levels in the media, ICC fibroblast copper levels are normal, but MT production is low. With added copper, which ICC cells take up normally (Fig. 6). MT synthesis fails to reach normal, induced levels (Fig. 4). A similar situation may occur in vivo. Hepatoxicity may develop in patients with ICC and high dietary copper ingestion, presumably because they fail to mount an MT response commensurate with the toxic copper load. The excess copper accumulates, causing the gradual hepatic deterioration characteristic of the disease. It follows that, at least in liver cells, the copper-sulfur aggregates should contain some copper not bound to MT.

In fact, such appears to be the case in the Bedlington terrier. whose liver contains electron-dense aggregates resembling those in ICC (36). These dogs store, on average, 27 times the normal amount of copper in their livers (37). However, the amount of hepatic MT RNA translation product has been shown to be in the normal range in the Bedlington terrier, and MT mRNA itself was only slightly more abundant than normal in this animal. The endogenous MT level, measured by mercury binding, was 6-fold normal in a single affected dog (37); the dog's MT would have to exhibit a 4-fold increase in copper saturation to bind all the additional copper present in the liver. Alternatively, some of the excess copper could remain unbound by MT. The situation in Bedlington terriers might then resemble that in ICC fibroblasts, whose MT levels are inducible by copper but not inducible to normal levels. We recognize that another possibility is that, in the Bedlington terrier, the MT content is appropriate but its level is underestimated by the mercury binding method because the MT is polymerized.

The finding that dexamethasone induces normal amounts of MT in ICC fibroblasts (Fig. $5 B$ ) is consonant with the hypothesis that ICC cells do not produce adequate MT in response to copper. The glucocorticoid regulatory element resides upstream of the metal regulatory elements and binds glucocorticoids rather than a metal regulatory factor. Consequently, any failure of copper to induce MT synthesis should not influence MT induction by dexamethasone. As a corollary, steroid therapy in patients with ICC might induce enough MT synthesis to handle a portion of

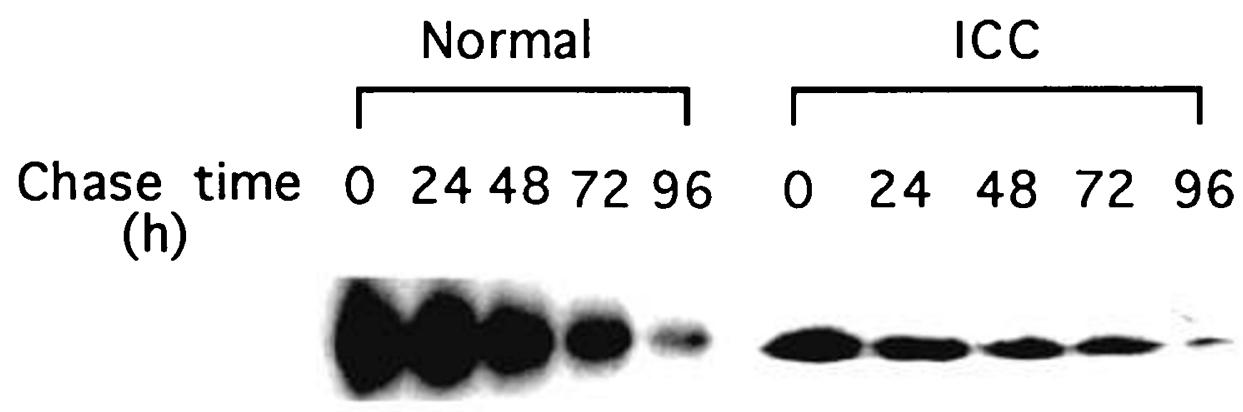

Fig. 7. ${ }^{35}$ S-MT degradation in normal and ICC fibroblasts. After a 9-h copper induction and 1-h ${ }^{35}$ S-cysteine labeling, normal (GM 3529 ) and ICC fibroblasts were exposed to cycloheximide and nonradioactive cysteine, and ${ }^{35} \mathrm{~S}-\mathrm{MT}$ was measured. Densitometry of this autoradiogram allowed calculation of a $t_{1 / 2}$ for MT degradation. 


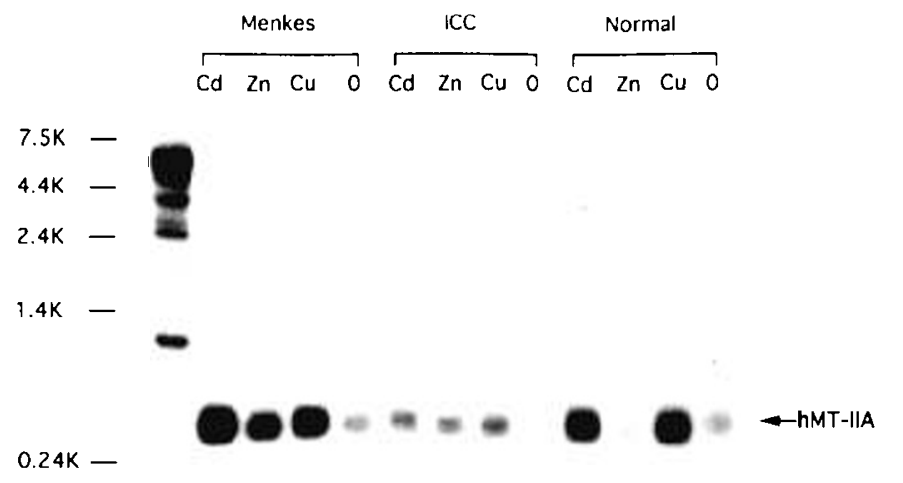

A

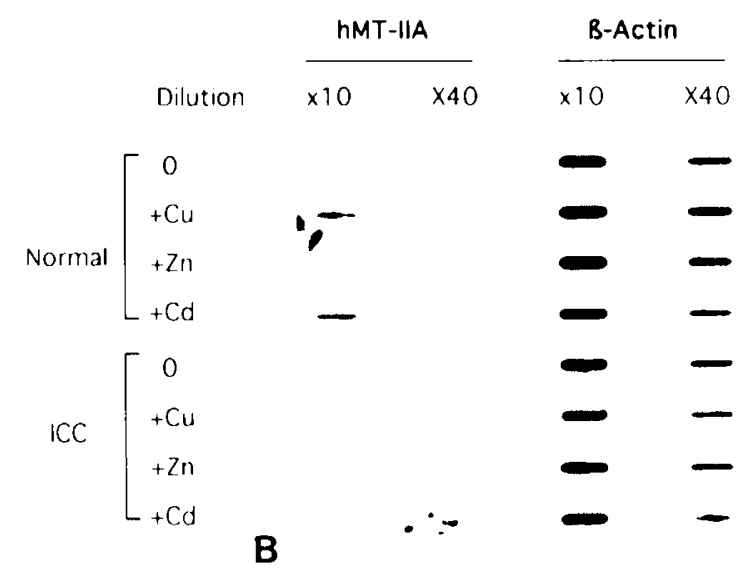

Fig. 8. hMT IIA mRNA studies. $A$, Northern blot of poly A mRNA from Menkes', ICC, and normal fibroblasts hybridized with ${ }^{32} \mathrm{P}$-labeled genomic hMT-IIA probe. Basal level is indicated by the $O$ lane: induced levels are for cadmium $(C d)(1 \mu \mathrm{M})$, zinc $(Z n)(100 \mu \mathrm{M})$, and copper (Cu) $(400 \mu \mathrm{M})$. Insufficient RNA was available for the normal zinc (normal $\mathrm{Zn}$ ) lane. The blot demonstrates the normal size of the ICC hMT IIA mRNA. $B$, Slot blot of poly A mRNA, normalized for amount loaded using $\beta$-actin mRNA. ICC hMT IIA mRNA is quantitatively less than normal under basal conditions $(O)$ and when induced by copper $(C u)(400 \mu \mathrm{M})$, zinc $(\mathrm{Zn})(100 \mu \mathrm{M})$, or cadmium $(C d)(1 \mu \mathrm{M})$.

the excess cellular copper, although existing tissue damage would almost certainly remain.

Several possible explanations exist for the proposed inability of copper, as well as zinc and cadmium, to induce enough MT synthesis to bind all intracellular metal ions. Intracellular copper, zinc, or cadmium may be consumed by binding to some overproduced molecule such as sulfide ion, making the metals unavailable to a metal regulatory factor. If this were true, the decreased MT synthesis would be a phenomenon resulting from the basic defect; in the case of ICC, the abnormal intracellular aggregates would consist of copper bound to the overproduced ligand. A defect in a metal regulatory factor might exist that is similar to the factor recently described in HeLa cell nuclear extracts (38). In particular, a single metal regulatory factor, which could normally bind either copper, zinc, or cadmium, might fail to bind either to its metal or to its metal regulatory element. Alternatively, three different metal regulatory factors might bind copper, zinc, and cadmium but share a common subunit mutated in ICC cells. In either event, the failure of copper, zinc, and cadmium to induce normal amounts of MT in vitro is consistent with isolated copper storage in ICC in vivo because affected individuals are exposed only to excess copper, not zinc or cadmium. Presumably, excess dietary zinc would result in intracellular zinc accumulation, perhaps accompanied by the formation of zinc-sulfur aggregates. A third possible explanation for decreased MT synthesis in response to metal induction would be a

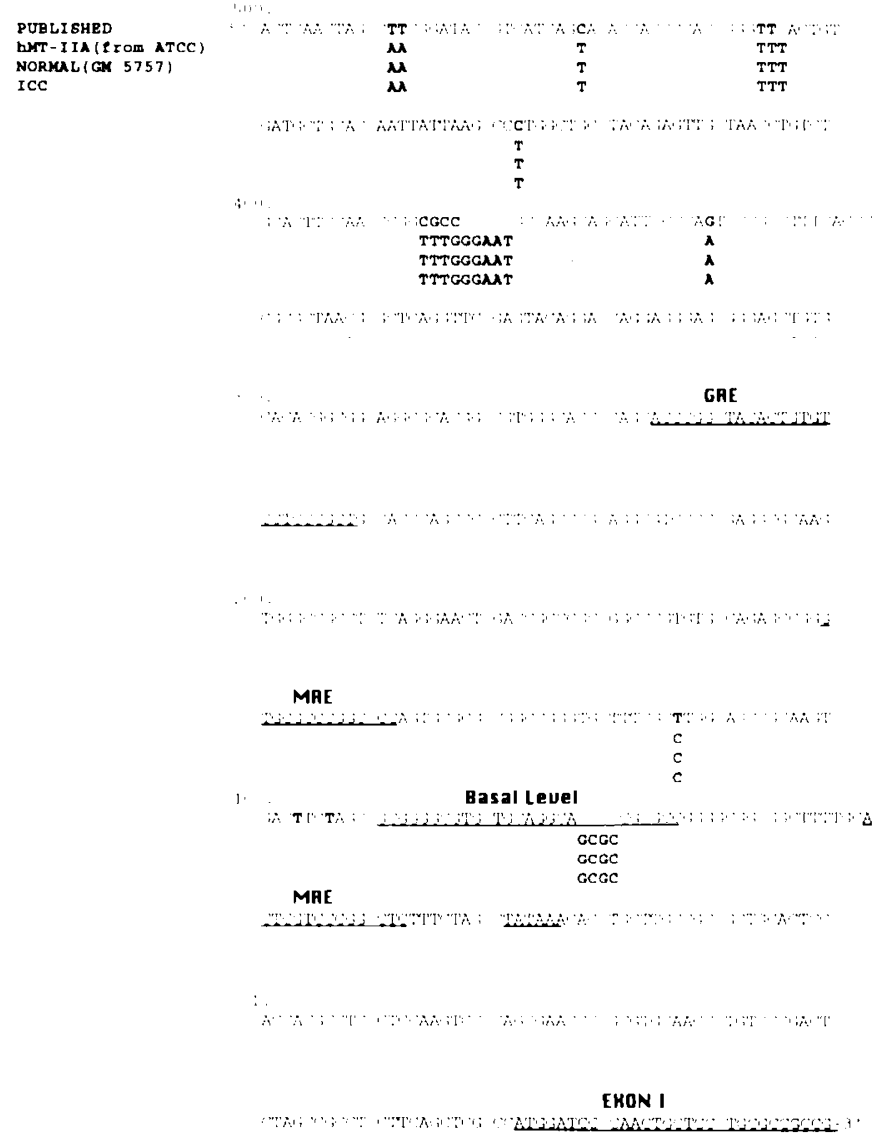

Fig. 9. Sequence of hMT IIA promoter regions. The published sequence (19) is compared with that of the ATCC clone, a normal (GM 5757) hMT IIA gene, and the ICC hMT IIA gene. Differences are noted in bold type. The glucocorticoid regulatory element. metal regulatory elements, and basal level element are underlined, as well as the TATAA box and exon 1. The published sequence is from Karin and Richards (19). and the location of the regulatory elements was published in Karin ct al. (20).

defective transcription factor that binds specifically to the hMT IIA basal level element.

These possibilities can be pursued now that the sequence of the hMT IIA promoter region has been determined with certainty. It will also be crucial to study other fibroblast strains to establish the range of normal and mutant rates of MT synthesis. with special emphasis on ICC cases from the Indian subcontinent. Finally, the copper aggregates and MT content of ICC livers deserve further investigation.

\section{REFERENCES}

1. Joshi VV 1987 Indian Childhood Cirrhosis. Perspect Pediatr Pathol 11:175192

2. Tanner MS 1986 Recent advances in pediatrics. In: Meadow R (ed) Indian Childhood Cirrhosis. Churchill Livingston, Edinburgh. Scotland, pp 103120

3. Portmann B. Tanner MS. Mowat AP. Williams R 1978 Orcein and liver deposits in Indian Childhood Cirrhosis. Lancet $1: 1838-1840$

4. Tanner MS, Williams R. Pandit AN. Mills CF, Bremner I 1979 Increased hepatic copper concentration in Indian Childhood Cirrhosis. Lancet 1:12031205

5. Popper H, Goldfischer S, Sternlieb I, Nayak NC, Madhavan TV 1979 Cytoplasmic copper and its toxic effects in ICC. Lancet 1:1205-1208

6. Goldfischer S, Popper H. Sternlieb I 1980 The significance of variations in the distribution of copper in liver disease. Am J Pathol 99:715-724

7. Tanner MS, Pallot D, Bulman S, Ibe K. King TP 1980 Intracellular localization of copper by energy dispersive microanalysis in Indian childhood cirrhosis. Acta Paediatr Belg 33:139

8. Adamson M, Reiner B. Olson JL, Goodman Z. Plotnick L, Bernardini I, Gah] 
WA 1992 Indian childhood cirrhosis in an American child. Gastroenterology 102:1771-1777

9. Agarwal SS, Lahori UC, Mehta SK. Smith DG. Bajpai PC 1979 Inheritance of Indian childhood cirrhosis. Hum Hered 29:82-89

10. Müller-Höcker J, Weiss M. Meyer U. Schramel P. Wichecke B. Belohradsky BH, Hubner G 1987 Fatal copper storage disease of the liver in a German infant resembling Indian childhood cirrhosis. Virchows Arch [Pathol Anat] 411:379-385

11. Walker-Smith JA. Blomfield J 1973 Wilson's disease or chronic copper poisoning? Arch Dis Child 48:476-479

12. Lefkowitch J, Honig CL, King M. Hagstrom JWC 1982 Hepatic copper overload and features of Indian childhood cirrhosis in an American sibship. N Engl J Med 307:271-277

13. Müller-Höcker J, Meyer U, Wiebecke B, Hubner G, Eife R, Kellner M. Schramel P 1988 Copper storage disease of the liver and chronic dietary copper intoxication in two further German infants mimicking Indian childhood cirrhosis. Pathol Res Pract 183:39-45

14. Maggiore G, De Giacomo C. Sessa F, Burgio GB 1987 Idiopathic hepatic copper toxicosis in a child. J Pediatr Gastroenterol Nutr 6:980-983

15. Bartok 1, Szabo L, Horvath E. Ormos J 1971 Juvenile zirrhose mit hochgradiger kupferspeicherung in der leber. Acta Hepato-Splenologica 18:119-128

16. Dunn MA, Bialock TL, Cousins RJ 1987 Metallothionein (425 25A). Proc Soc Exp Biol Med 185:107-119

17. Nielson KB, Winge DR 1984 Preferential binding of copper to the b domain of metallothionein. J Biol Chem 259:4941-4946

18. Palmiter RD. Findley SD. Whitmore TE. Durnam DM 1992 MT-III a brainsepcific member of the metallothionein gene family. Proc Natl Acad Sci USA 89:6333-6337

19. Karin M, Richards RI 1982 Human metallothionein gene-primary structure of the metallothionein Il gene and a related processed gene. Nature 299:792802

20. Karin M, Haslinger A, Holtgreve H. Richards RI. Krauter P. Westphal HM, Beato M 1984 Characterization of DNA sequences through which cadmium and glucocorticoid hormones induce human metallothionein-IIA gene. Nature 308:513-519

21. Barka T. Anderson PJ 1962 Histochemical methods for acid phosphatase using hexazonium pararosaniline as coupler. J Histochem Cytochem 10:741-753

22. Durnam DM, Perrin F, Gannon F. Palmiter RD 1980 Isolation and characterization of the mouse metallothionein I gene. Proc Natl Acad Sci USA $77: 6511-6515$
23. Anderson CW, Straus JW. Dudock BS 1983 Preparation of a cell-free proteinsynthesizing system from wheat germ. Methods Enzymol 101:635-644

24. Smith PK, Krohn RI, Hermanson GT, Mallia AK. Gartner FH. Provenzano MD, Fujimoto EK. Goeke NM. Olson BJ, Klenk DC 1985 Measurement of protein using bicinchoninic acid. Anal Biochem 150:76-85

25. Sambrook J, Gritsch EF. Maniatis T 1989 Molecular Cloning. A Laboratory Manual. Cold Spring Harbor Laboratory. New York

26. Feinberg AP. Vogelstein B 1983 A technique for radiolabeling DNA restriction endonuclease fragments to high specific activity. Anal Biochem 132:6-13

27. Feinberg AP. Vogelstein B 1984 Addendum: a technique for radiolabeling DNA restriction endonuclease fragments to high specific activity. Anal Biochem 137:266-267

28. Lehrach H, Diamond D. Wozney JM. Boedtker H 1977 RNA molecular weight determinations by gel electrophoresis under denaturing conditions. A critical reexamination. Biochemistry 16:4743-4751

29. Sanger F. Nicklen S. Coulson AR 1977 DNA sequencing with chain-terminating inhibitors. Proc Natl Acad Sci USA 74:5463-5467

30. Leone A. Pavlakis GN. Hamer DH 1985 Menkes' disease: abnormal metallothionein gene regulation in response to copper. Cell 40:301-309

31. Danks DM 1989 The metabolic basis of inherited disease. In: Scriver CR Beaudet AL. Sly WS, Valle D (eds) Disorder of copper transport. McGrawHill. New York, pp i4!1-143!

32. Luzzatto L. Mehta A. 1989 The metabolic basis of inherited disease. In: Scriver CR. Beaudet AL, Sly WS, Valle D (eds) Glucose-6-phosphate Dehydrogenase Deficiency. McGraw-Hill. New York. pp 2237-2265

33. Thiele DJ 1988 ACEI regulates expression of the Saccharomices cerevisiae metallothionein gene. Mol Cell Biol 8:2745-2752

34. Fürst P, Hu S. Hackett R. Hamer D 1988 Copper activates metallothionein gene transcription by altering the conformation of a specific DNA binding protein. Cell 55:705-717

35. Fürst P. Hamer D 1989 Cooperative activation of a eukaryotic transcription factor: interaction between $\mathrm{Cu}(\mathrm{I})$ and yeast ACE1 protein. Proc Natl Acad Sci USA 86:5267-5271

36. Johnson GF. Morell AG. Stockert RJ. Sternlieb I 1981 Hepatic lysosomal copper protein in dogs with an inherited copper toxicosis. Hepatology 1:243248

37. Hunt DM, Wake SA, Mercer JFB. Danks DM 1986 A study of the role of metallothionein in the inherited copper toxicosis of dogs. Biochem J 236:409-415

38. Koizumi S, Suzuki K. Otsuka F 1992 A nuclear factor that recognizes the metal-responsive elements of human metallothionein IIA gene. J Biol Chem 267:18659-18664 